\title{
Teaching Materials Development of Indonesian Language Based on Islamic Text in Islamic Universities
}

\author{
Firman", Arifin Ahmad, Anshari \\ Post Graduate Program, State University of Makassar, Indonesia
}

Received July 16, 2020; Revised December 30, 2020; Accepted January 20, 2021

\section{Cite This Paper in the following Citation Styles}

(a): [1] Firman, Arifin Ahmad, Anshari, "Teaching Materials Development of Indonesian Language Based on Islamic Text in Islamic Universities," Universal Journal of Educational Research, Vol. 9, No. 1, pp. 1 - 9, 2021. DOI: 10.13189/ujer.2021.090101.

(b): Firman, Arifin Ahmad, Anshari (2021). Teaching Materials Development of Indonesian Language Based on Islamic Text in Islamic Universities. Universal Journal of Educational Research, 9(1), 1 - 9. DOI: 10.13189/ujer.2021.090101.

Copyright $\mathrm{C} 2021$ by authors, all rights reserved. Authors agree that this article remains permanently open access under the terms of the Creative Commons Attribution License 4.0 International License

\begin{abstract}
Teaching materials development in Islamic universities is oriented to the concept of scientific integration which is expected to contribute positively to the development and study of Islam. This study aims to develop valid, practical and effective Indonesian language teaching materials at the Institut Agama Islam Negeri (IAIN) Palopo. This research is a research and development (Research and Development) using the Borg \& Gall model involving 117 students, 6 Indonesian lecturers, and 2 Indonesian language learning experts[1]. The research instrument is questionnaire validation of teaching materials which included aspects of material, presentation, graphic and language, observation sheet of practicality of teaching materials, and student achievement test. This study produced a textbook with the title "Indonesian Language for Islamic Universities". This book was developed based on the needs of students and lecturers at IAIN Palopo. Based on the analysis results, the validity of this textbook is in the category of very valid. The quality of this textbook is equivalent to the results of the learning implementation. The response of students and lecturers, observations of the implementation of learning and student learning outcomes showed positive results. This is supported by quantitative data obtained from the results of descriptive and inferential statistical analysis.
\end{abstract}

Keywords Teaching Material, Indonesian Language, Islamic Text

\section{Introduction}

Since the entry of the Decree of the Director General of Higher Education Ministry of National Education of the Republic of Indonesia number 43 / DIKTI / Kep / 2006 article 6 line 2 concerning the Signs of the Implementation of Personality Development Subjects in Higher Education[2], Indonesian as a general course must have been taught in all high institutions in Indonesia. This Indonesian language course aims to achieve students' proficiency in using Indonesian language to master, apply, and develop science, technology, and art with a sense of responsibility as a citizen of Indonesia with personality. The implementation of Indonesian language learning in high institutions is still experiencing many obstacles. These constraints are caused by various factors, including students' negative attitudes towards Indonesian language, Indonesian language learning systems and models that are not ideal yet, and lack of teaching materials that fit the needs of students [3]. On the other hand, learning Indonesian courses has so far only been in the spelling and sentence structure areas. Regarding Indonesian language teaching materials, each university is given the freedom to develop their own curriculum based on the Decree of the Minister of National Education RI No. 232 / U / 2000[4].The development of this teaching material should be arranged based on needs with consideration of the relevance of the higher education scientific studies.

Research on learning Indonesian in universities in Indonesia tends to look at two aspects. First, studies that look at aspects of the implementation of learning[5]. The 
second trend, studies that look at aspects of the development of learning materials[6]. As Rahmiati said, Indonesian teaching materials were not accommodated through books available in bookstores. In addition, the material taught tends to repeat the material at the previous educational level[7]. [8] states that designing teaching materials must take into account student needs, situations, curriculum objectives, and so on[8]. Teaching material is very important for lecturers and students. For lecturers, teaching materials play an important role in saving teaching time, changing the role of lecturers to become facilitators, and creating more effective and interactive learning. For students, teaching materials can help students learn material and help their ability to learn independently. In addition, the presence of teaching materials is developed according to needs. Teaching materials will also direct learning activities in accordance with the planned competency achievements[9].

This research complements the lack of Indonesian teaching materials in Islamic religious tertiary institutions by developing teaching materials using Islamic texts on the materials. This text is using to familiarize students with using language or terms related to Islamic studies. This habituation expects to have broad implications and improve the ability to speak Indonesian for Islamic academic, social and religious needs for students [10]. It is necessary to have teaching materials that are complete, systematic, and present examples tailored to students' characteristics and integrated with Islamic material. Considering the number of Islamic educational institutions in Indonesia, textbooks based on Islamic discourse and values are necessary [11]. This finding is expected to be a solution to the lack of Indonesian language teaching materials in Islamic religious tertiary institutions in Indonesia. In addition, the instruments developed in this research have the potential to be used in further studies in different fields or disciplines such as health, economics, and other fields.

This paper is based on the argument that (1) Indonesian Language courses in Islamic universities (PTKI) can make a positive contribution in the development and study of Islamic science; (2) This text-based learning method is carried out on text units with the aim to carry out various communicative actions in a meaningful way, by using or relating to texts that are beneficial to the lives of students, receptively and productively, verbally and in writing, in various contexts relevant to student life, in the form of speaking, listening, reading and writing activities that are naturally integrated in meaningful communicative activities; (3) In addition to studying fields of science that are in accordance with the course of study, students of Islamic religious colleges also carry the mission of preaching so that what is thought can be conveyed eloquently and easily understood.)

\section{Review of Related Study}

Several researchers have conducted a study of general Indonesian language teaching materials. The research conducted by [6] examined the development of Indonesian language teaching materials at STMIK Palangka Raya. This development research has produced teaching materials that have been tested for validity, effectiveness and practicality. The analysis shows the validity of textbooks is $93 \%$, effective because $92.67 \%$ of students complete KKM, and practical because $87.33 \%$ of students responded to the applicability of the product well, and $89.60 \%$ of practitioners responded well when applied. Teaching materials are developed equip students to be able to apply the rules of Indonesian Language that are good and right, in the fields of science and technology and in everyday life[6].

In another study, Helaluddin examined the analysis of Indonesian language learning needs of students in syariah economics study program at UIN Banten. Participants in this study were 60 first semester students of Islamic Economics Study Program in the academic year of 2017/2018 and several lecturers. The data in this study were qualitative descriptive data obtained through interviews and questionnaires. The data were the problems faced by students and the needs or desires of students while studying Indonesian language courses at UIN Banten. The results of the study stated about the needs of students and the views of lecturers in learning Indonesian language, which included dimensions of content, learning strategies, language variety, learning objectives, literary learning, and assessment [12].

Research on Indonesian language teaching materials was also carried out on students at Bosowa University of Makassar by integrating local cultural values in classical poetry (Elompugi) as an alternative, in an effort to preserve local culture, by appreciating literary works into teaching materials based on character education. The teaching material in this study was developed with the Four D model. The results showed that the Indonesian language teaching material that was developed based on the value of "elong ugi" was eligible and suitable to be used [13]. Rahmiati also developed Indonesian language teaching materials at UIN Alauddin Makassar. This research develops teaching materials based on the integration of Islamic knowledge by including related verses or traditions, raising Islamic themes as reading material and examples[7].

[14] conducted a research based on Islamic literary texts. His study tried to strengthen the existence of Islamic literature by proposing a theological and social footing of Islamic literature and possible learning strategies in teaching English in contemporary Indonesia. Research development methods and literature studies are used in data collection and processing. This study shows that Islamic literature has a strong theological footing and an 
established social footing. Another finding is that the use of appropriate visualization, exploitative texts, and 'relevant glosses' is an effective learning strategy.

Islamic text-based research was also conducted by [11] This research was conducted on English teaching material in Muhammadiyah schools using a qualitative approach. This study concludes that the need for Islamic-based English language teaching materials is needed for Muhammadiyah schools to achieve national education goals and for the Islamic faith itself. Development based on a text-based approach by replacing content with content related to Islam.

Teaching material is a set of subject matter that refers to the curriculum used in order to achieve predetermined competency standards and basic competencies. The positive impact of teaching materials is that lecturers will have more time to guide students in the learning process and help students to gain new knowledge from all sources or references used in teaching materials. Teaching materials need to be selected and presented appropriately so that learning outcomes are reached to the maximum so that students feel satisfied that they can access teaching materials from anywhere with pleasant learning conditions[15].

The language learning paradigm in the school curriculum and higher education is currently directed at text-based learning. Text-based Indonesian learning is the process of learning Indonesian that is carried out by students whose starting point is the understanding of the text and towards making the text [16]. Text-based learning is carried out by applying the principle that language should be seen as text, not merely a collection of words or language rules. Also, the use of language is the process of selecting linguistic forms to express meaning.

The functional language can not release from the context of the language form used and reflected in ideas, attitudes, and values; also, the language is a means of forming human thinking. In connection with that principle, each text has a different structure. Each text structure in each text has language tools to express the desired thoughts in each text structure and is integrally oriented towards achieving the overall social goals.

For this reason, in text-based learning the discussion about lexical units, grammatical (grammar) must be in the form of talks about linguistic units related to the structure of thought which is the social goal of the text, not fragments. To understand texts requires interaction between the reader and the text in which the reader must link ideas from the text to his background knowledge to construct the meaning of the text[17]. Thus, each text which is an expression of a social process (certain genre) that takes place in the context of a particular situation has a load of cultural values or norms.

The use of text also aims to foster an attitude of respect and living religious and social values, including honesty, discipline, responsibility, care (tolerance, cooperation), politeness, confidence in interacting effectively with the social and natural environment within reach of relationships and its existence. Utilizing various texts by the relevance of science in developing teaching materials is one of the efforts to achieve educational goals and make it easier for students to learn learning materials already familiar with or learn about the text's contents. The same thing with Irwan's statement[18] in his research uses Islamic texts in reading learning. Students who are familiar with the text will be helped in understanding the text so that they are also easy in answering reading questions.

Islamic religious tertiary institutions' operational concept is an accumulation of civilizing, inheriting and developing Islamic teachings, Islamic culture, and civilization from generation to generation. To achieve this, Islamic religious colleges must be inclusive and open to the times. The dichotomic building of knowledge between general science and religious science must transform into new scientific buildings that are more integral or complementary [10]. Furthermore, [19] states that graduates of Islamic tertiary institutions expect to attend functionally to answer and solve the ummah's problems, not to be trouble makers. Health problems are so complicated, so answering challenges and problems is not enough with just one scientific dimension. Therefore, Islamic University scholars expect to think wisely by taking various scientific angles to take action wisely.

\section{Methodology}

This study applies a research and development approach using the Borg \& Gall model. The Borg \& Gall model has been used by previous researchers who have focused on developing teaching materials[20]. In this study, the Borg and Gall models were modified into 5 steps, namely (a) needs analysis, (c) design, (d) development, (e) implementation, (f) dissemination[1]. The first stage needs analysis. A survey and analysis of the semester learning plan for Indonesian courses are carrying out at this stage. It aims to determine the needs of users (students and lecturers). The second stage is the design - a redesign of Indonesian language teaching materials, including material and visual aspects. The third stage is the development. This stage is carried out by a validation test and then tested in the form of small groups and large groups. The fourth stage, implementation. At this stage, teaching materials are implemented in learning to determine the level of practicality and effectiveness. The fifth stage, dissemination. At this stage, teaching materials that have met the criteria of being valid, practical, and effective are ready for use and disseminated after obtaining a recommendation from the user institution leader. This research involved 117 students of [2]class 2018 and 2019 at the Madrasah Ibtidaiyah Teacher 
Education Study Program FTIK IAIN Palopo, 6 Indonesian lecturers from IAIN Palopo, 2 Indonesian language learning experts from Makassar State University. Data collection was obtained using a questionnaire of teaching material needs, a questionnaire validating teaching materials, a questionnaire for student and lecturer responses, an observation guideline for the implementation of learning, and a student learning outcomes test sheet. An instrument of needs analysis in the form of a questionnaire containing closed questions was filled in by 84 PGMI FTIK IAIN Palopo class of 2018 students who had attended the Indonesian language course.

The validity test of teaching materials is carried out by developing a questionnaire with four components which are assessed namely aspects of content, presentation, graphics, and language[21]. The practicality of teaching materials can be seen from the consistency of three assessment results, including (1) the results of the assessment conducted by students through field trials conducted twice in the form of small group trials and large group trials revealed that the teaching materials developed were in the feasible category ; (2) the results of the response of 6 Indonesian lecturers to the teaching material developed were in the feasible category; (3) the evaluation conducted by the observer shows that the implementation of learning by using teaching materials from the development results is included in the good category, as seen by three aspects of observation, namely introductory, core, and closing activities [22]. This teaching material was delivered in six meetings. The effectiveness of teaching materials is measured by conducting experiments with the One Group Pretest-Posttest Design [23]. Data analysis techniques consist of descriptive statistics. Descriptive statistics aim to describe the level of validity of teaching materials, student and lecturer questionnaire responses, the results of learning outcomes, and student learning outcomes. Another data analysis technique used in this study is paired sample t-test which is part of inferential statistics. It aims to find out whether the teaching materials applied can significantly improve student learning outcomes. Qualitative data consisting of interviews and observations were analyzed using a qualitative descriptive approach.

\section{Results}

\subsection{Need Analysis}

The survey results of 84 students of Madrasah Ibtidaiyah Teacher Education Study Program 2018 who have used these teaching materials show that $13 \%$ stated the teaching material was interesting, $12 \%$ stated the teaching material was boring, and $75 \%$ stated the teaching material was ordinary. Related to the development of teaching materials, the results of 84 student questionnaires showed that $92.85 \%$ wanted Indonesian teaching materials to be integrated with Islamic materials. Likely the students, several Indonesian Language lecturers at IAIN Palopo also expressed the importance of including Islamic texts in learning the Indonesian language. Based on the interview results with the Indonesian Language lecturer, Islamic texts in learning Indonesian have a double benefit; first, students can already learn the language. Secondly, the students get information or religious knowledge from the read text. Other positive responses were also Indonesian lecturers in IAIN Palopo, stating that it was appropriate for lecture materials to get an 'Islamic' touch so that a strong Islamic character would be performing, and this was in line with the vision of the IAIN Palopo.

\subsection{The Prototype of Teaching Materials Development Results}

The analysis results of the need for teaching materials are used as study material to develop Indonesian language teaching materials. The study's substance or teaching material is developing from the semester learning plan (RPS) of Indonesian Language courses. This teaching material developed from the IAIN Palopo by integrating Islamic study texts as study materials for language learning. The text is obtaining from various sources, both books and online sources. The developed textbook is entitled "Indonesian Language for Islamic Religious Colleges." The media used for this teaching material were in the form of textbooks. The material developed in this teaching material book based on the semester learning plan (RPS), namely (1) History and development of Indonesian language; (2) Indonesian language variety of scientific; (3) Dictionary (word choice); (4) Formation and expansion of sentences; (5) Formation of paragraphs; (6) Reading skills; (7) Writing skills; (8) Speaking skills.

The textbook material design's graphical aspect is as attractive as possible; also, the cover image is designed with bright colors and gives an Islamic impression. The book's size uses the UNESCO standard that is B5 size $(15.5 \times 23 \mathrm{~cm})$. The font used is Cambria type with size 12 and uses space 1.15. The choice of book size and type of font is based on a need's analysis questionnaire.

\subsection{Product Validity of Teaching Materials}

There are four components that are assessed for validity in teaching material products developed as stated by [21], namely material, presentation, graphic, and language[21]. The validity level of some of these aspects in the teaching material developed is shown in the following table. 
Table 1. Results of Test Validity of Teaching Materials

\begin{tabular}{|c|c|c|c|c|}
\hline \multirow{2}{*}{ Component } & \multicolumn{2}{|c|}{ Validator 1} & \multicolumn{2}{|c|}{ Validator 2} \\
\hline & Tahap 1 & Tahap 2 & Tahap 1 & Tahap 2 \\
\hline Material & $\begin{array}{c}56,47 \\
\text { (Valid enough)) }\end{array}$ & $\begin{array}{c}84,70 \\
\text { (Very Valid) }\end{array}$ & $\begin{array}{c}57,64 \\
\text { (Valid enough)) }\end{array}$ & $\begin{array}{c}83,52 \\
\text { (Very Valid) }\end{array}$ \\
\hline Presentation & $\begin{array}{c}53,84 \\
\text { (Invalid) }\end{array}$ & $\begin{array}{c}90,76 \\
\text { (Very Valid) }\end{array}$ & $\begin{array}{c}49,23 \\
\text { (Invalid) }\end{array}$ & $\begin{array}{c}87,69 \\
\text { (Very Valid) }\end{array}$ \\
\hline Graphics & $\begin{array}{c}54,61 \\
\text { (Valid enough)) }\end{array}$ & $\begin{array}{c}86,15 \\
\text { (Very Valid) }\end{array}$ & $\begin{array}{c}51,53 \\
\text { (Invalid) }\end{array}$ & $\begin{array}{c}88,46 \\
\text { (Very Valid) }\end{array}$ \\
\hline Language & $\begin{array}{c}54.54 \\
\text { (Valid enough)) }\end{array}$ & $\begin{array}{c}94,54 \\
\text { (Very Valid) }\end{array}$ & $\begin{array}{c}56,36 \\
\text { (Valid enough)) }\end{array}$ & $\begin{array}{c}89 \\
\text { (Very Valid) }\end{array}$ \\
\hline
\end{tabular}

From table 1, it can be seen that the teaching material developed has a high level of validity. In the first stage of the assessment there were still a number of weaknesses or errors thus the validators gave there which assessed the invalid and quite valid. The validity standard of teaching materials required must be in a minimum valid category or very valid. Therefore, all forms of weaknesses or mistakes encountered in the first stage of assessment must be revised. Next, the revision results are checked again to find out the validity level. The average score from the accumulation of stage 2 scores from the two validators is 88.10 with a very valid category. From the average score, it means that the teaching materials have a high quality in four aspects namely materials, presentation, graphics and language.

\subsection{Practicality of Teaching Materials}

The practicality of Indonesian text-based teaching material products based on Islamic texts is known based on students' responses or responses in field trials and Indonesian language lecturers' responses at IAIN Palopo. Field trials carrying out twice, namely small group trials and large group trials - the results of small group trials present in table 2 .

Table 2. Small-Group Test Results

\begin{tabular}{cccc}
\hline Interval & Category & Frequency & Percentage \\
\hline 39 above & Very good & 0 & 0 \\
$30-38$ & Good & 10 & 100 \\
$21-29$ & Enough & 0 & 0 \\
12 under & Less & 0 & 0 \\
Total & & 10 & 100 \\
\hline
\end{tabular}

Table 2 shows that the responses of trial subjects have a positive tendency. In this small group trial, students respond to teaching materials in either category by $100 \%$. The total response score of 10 test subjects was 333 or $83.25 \%$. Next, the results of the large group trial are presented in table 3 .
Table 3. Large Group Test Results

\begin{tabular}{cccc}
\hline Interval & Category & Frequency & Percentage \\
\hline 39 above & Very good & 0 & 0 \\
$30-38$ & Good & 26 & 79 \\
$21-29$ & Enough & 7 & 21 \\
12 under & Less & 0 & 0 \\
Total & & 33 & 100 \\
\hline
\end{tabular}

Table 3 shows that the responses of large-group trial subjects have the same tendency as the results of small-group responses. In addition to responses from students, researchers also gave a questionnaire response to lecturers of Indonesian language courses at IAIN Palopo, amounting to 6 people. Lecturer responses to teaching materials with a total score of 275 are at intervals of 253 $300(84 \%$ - $100 \%)$ with the category "very good". The results of the interviews that supported the lecturers' responses included (a) textbooks which were guided by the semester learning plan (RPS) of Indonesian language courses, (b) the existence of scientific integration by utilizing Islamic texts in learning which was very relevant to the needs of Islamic religious tertiary students, (c) coherent teaching materials accompanied by evaluation facilitate the learning process.

The feasibility of teaching materials tests is carried out by observing learning for seven meetings. The aspects observed in Indonesian language learning include; aspects of initial activities, aspects of core activities, and closing activities. The score of observations on all three is 1.7. From the observation results obtained, it knows that the average score obtained is at an interval of $1.5 \leq \mathrm{KM} \leq 2.0$, and then the learning activities are carried out entirely. Based on this, the Indonesian teaching materials for Islamic religious colleges are declared to meet practical criteria. The score obtained is based on the observation result that the implementation of teaching materials are included in the "fully implemented" category [22].

\subsection{Effectiveness of Teaching Material Products}

The pre-treatment learning outcomes above are presented in table 5 which shows the tendency of 33 student pretest results. 
Table 5. Student Pretest Score Results

\begin{tabular}{cccc}
\hline Interval & Category & Frequency & Percentage \\
\hline 32 above & Very high & 0 & 0 \\
$24-31$ & High & 7 & 21 \\
$16-23$ & Medium & 26 & 79 \\
$8-15$ & Low & 0 & 0 \\
Seven under & Very Low & 0 & 0 \\
Total & & 33 & 100 \\
\hline
\end{tabular}

Furthermore, data on learning outcomes after treatment can be seen in table 6 .

Table 6. Student Posttest Score Results

\begin{tabular}{cccc}
\hline Interval & Category & Frequency & Percentage \\
\hline 32 above & Very high & 18 & 55 \\
$24-31$ & High & 15 & 45 \\
$16-23$ & Medium & 0 & 0 \\
$8-15$ & Low & 0 & 0 \\
Seven under & Very Low & 0 & 0 \\
Total & & 33 & 100 \\
\hline
\end{tabular}

To evaluate whether there was a significant increase in student learning outcomes after attending seven lecture meetings using this teaching material, the t test was used. The analysis results are shown in table 7 .

Table 7 shows that there was an increase of 10.79 after attending seven college meetings and the t-count was negative, amounting to $-15,717$. This t-count score is negative because it is the average score of pretest learning outcomes which is lower than the average posttest learning outcomes. Furthermore, in the results of this study, a negative t-count value can be positive so that the t-count value becomes 15.72. The value of $\mathrm{df}$ is 32 and the value of $0.05 / 2$ is equal to 0.025 . This value is used as a basis for finding the value of $t$ table in the distribution of the $t$ value of a statistical table that produces a value of $t$ table 2.021. Thus, because the value of $t$ arithmetic $15.717>t$ table 2.021 , then as a basis for decision making it can be concluded that $\mathrm{H} 0$ is rejected and $\mathrm{Ha}$ is accepted so that it can be concluded that there is an average difference between pretest and posttest learning outcomes which means there is an influence on the use of Indonesian teaching materials Islamic text based at IAIN Palopo. Therefore, this teaching material is proven effective in improving student learning outcomes.

Table 7. Interpretation of the "Paired Samples Test" Output Table

\begin{tabular}{|c|c|c|c|c|c|c|c|c|c|}
\hline \multicolumn{10}{|c|}{ Paired Samples Test } \\
\hline & & \multicolumn{5}{|c|}{ Paired Differences } & \multirow{3}{*}{$\mathrm{t}$} & \multirow{3}{*}{$\mathrm{df}$} & \multirow{3}{*}{$\begin{array}{c}\text { Sig. } \\
\text { (2-tailed) }\end{array}$} \\
\hline & & \multirow{2}{*}{ Mean } & \multirow{2}{*}{ Std. Deviation } & \multirow{2}{*}{$\begin{array}{l}\text { Std. Error } \\
\text { Mean }\end{array}$} & \multicolumn{2}{|c|}{$\begin{array}{l}95 \% \text { Confidence Interval of the } \\
\text { Difference }\end{array}$} & & & \\
\hline & & & & & Lower & Upper & & & \\
\hline Pair 1 & $\begin{array}{l}\text { pretest - } \\
\text { posttest }\end{array}$ & -10.78788 & 3.94301 & .68639 & $-12.18601-$ & $-9.38975-$ & $-15.717-$ & 32 & .000 \\
\hline
\end{tabular}




\section{Result and Discussion}

This research aims to develop Indonesian teaching materials based on Islamic texts that are valid, practical, and effective - this textbook design meets users, students, and lecturers' needs. Previous studies have noted the importance of analyzing needs before compiling teaching materials [24] [25] [11]. The needs analysis results show that students and lecturers want a teaching material with Islamic religious material. This analysis supports the results of studies conducted by [26] which state that a person cannot escape from the cultural background and values that have shaped it. For them, the use of Islamic religious material in learning Indonesian has several advantages. For them, the use of Islamic religious material in learning Indonesian has several advantages. The advantage in question is that the Islamic religious material presented is likely to have been known to make it easier to make a linguistic analysis. Also, the information presented can add Islamic insight. As a general course in tertiary institutions, the Indonesian language aims to achieve language proficiency by mastering, applying, and developing science, technology, and art with a sense of responsibility. To that end, in line with what was stated by [27], learning the Indonesian language requires a deep understanding to produce texts that are spoken and written in a global nuance of Indonesia. Islamic Education Institutions should direct to give birth to human resources to enter the era of globalization, the era of industrialization and the information age [19].

In this study, the development of Indonesian language teaching materials is carried out by utilizing Islamic religious texts to present the material. In line with this, [11] stated that Islamic values can be an alternative to be integrated into teaching materials because they are in accordance with the objectives of Indonesia's national education because the number of Islamic-based schools in Indonesia is very large. Therefore, the development of teaching materials based on Islamic values is needed. Text forms integrated into teaching materials are (1) Islamic historical texts, (2) Lecture or sermon texts, (3) Quotations and translations of Quranic verses and Hadiths, (4) Articles, and (5) Islamic literary works [28]. The texts are obtaining from various sources such as books, magazines, scientific journals, and the internet. Indonesian teaching materials based on Islamic texts are presented in a standard size UNESCO textbook format. The selection of textbooks as teaching media is carried out, assuming that textbooks are more comprehensive than modules or other teaching materials. This textbook bases on the semester learning plan (RPS) used in Indonesian language courses at IAIN Palopo. The researcher also examined the Indonesian RPS from several Islamic religious colleges to find the possibility of developing material in textbooks. One of the principles of developing teaching materials, as proposed by [29], is collaboration. Collaboration with various relevant parties can enrich and increase the quality of teaching materials developed.

The developed text book is entitled "Indonesian Language for Islamic Religious Colleges". Based on research conducted by [30], it states that $79 \%$ of teachers prefer teaching materials in the form of textbooks. In the graphic aspect, the selection of Cambria 12 font with 1.15 spaces is intended to give a serious impression in this book. The Cambria font is usually used for academic texts. The cover design or aspect of the textbook material is designed as attractive as possible. The cover image was designed using red and white against the background of the map of the Republic of Indonesia intending to illustrate the spirit of Indonesia. The dome silhouette of the mosque with some calligraphy ornaments gives the impression of Islam. Teaching materials are arranged in eight parts and arranged systematically based on problem orientation. At the end of each section there is an evaluation in the form of an ability test and a skills test. The compilation of sections in this book was developed to make it easier to see the progress of student learning outcomes. It is in line with the modeling of teaching material content developed by [31].

Indonesian textbook products based on Islamic texts are considered valid. The results of the test of the validity of teaching materials show that the component content, presentation, graphic, linguistic, and media components have met the ideal teaching material standards based on an expert assessment of two people from the Indonesian Language and Literature Education Study Program, Makassar State University. The validity test results from the two expert validators showed a score of 88.10. This score is categorized as very valid so it is very feasible to be developed as a reference for teaching materials in tertiary institutions especially Islamic religious tertiary institutions.

The use of Indonesian Islamic text-based teaching materials gets a positive response and is able to improve student learning outcomes. In general, the implementation of this learning shows that the Indonesian learning process is carried out with systematic steps. Field trials were carried out twice, namely small group trials and large group trials with results in the "good" category. Likewise, the response of lecturers to teaching materials is in the category of "very good". The results of the implementation test of learning Indonesian for seven meetings resulted in a score of 1.7. From the observation results obtained, it is known that the average score obtained is at an interval of $1.5 \leq \mathrm{KM} \leq 2.0$, then the learning activities are carried out entirely. Positive results of the implementation of this learning are influenced by two factors, namely teaching material and teaching factors. These two factors complement each other. Teaching material is a representation of the explanation of the teaching staff in front of the class. Information and descriptions must be submitted, and information presented 
by teaching staff are collected in teaching materials[32].

They have improved student learning outcomes from the acquisition of pretest and post-test. The pretest score of dominant students is in the medium category or $79 \%$, and after attending seven meetings, the post-test score is in the high and very high category. There are positive results due to several factors. First, teaching materials are developed based on the analysis of teaching needs; [12]. Second, students have received text-based learning during high school. Third, students already have basic knowledge about the Islamic text used so that it is easier to understand. Informative textbooks can add insight and support other relevant studies.

This Indonesian textbook can be applied globally in Indonesia, especially in Islamic religious colleges under religion's ministry. At present, based on data from the Directorate General of Islamic Education, State Islamic Religious Colleges (PTKIN) number 58 colleges and 649 Private Islamic Religious Colleges (PTKIS)[33]. The extraordinary potential must get attention from various parties so that Indonesian language courses' objective is by the Decree of the Director-General of Higher Education Ministry of National Education of the Republic of Indonesia number 43 / DIKTI / Kep / 2006 article 6 paragraph 2. Namely, to achieve student skills in using Indonesian to mastering, applying, and developing science, technology, and art with a sense of responsibility as Indonesian citizens with personality can be realized [2].

\section{Conclusions}

This study aims to develop Indonesian language teaching materials based on Islamic texts that are valid, practical, and effective. This development textbook is entitled "Indonesian Language for Islamic Universities." This book was developed based on the needs of students and lecturers at IAIN Palopo. Based on the analysis results, the validity of this textbook is in the category of very valid. Indonesian language learning experts carry out validation based on material, presentation, graphics and language. The quality of this textbook is equivalent to the results of the learning implementation. Student and lecturer responses and student learning outcomes show positive results. It is supporting by quantitative data obtained from the results of descriptive and inferential statistical analysis.

The findings consider for choosing Indonesian language teaching materials within the scope of IAIN Palopo. On a broader scale, this teaching material expects to use as Indonesian teaching material at Islamic universities (PTKI) throughout Indonesia. Furthermore, this study's instruments can develop in the research of Indonesian teaching materials in different fields or disciplines such as Indonesian for health, economics, and other fields.

\section{REFERENCES}

[1] Borg G. Education Research. New York: Allyn and Bacon; 2003.

[2] Depdiknas. Rambu-Rambu Pelaksanaan Kelompok Matakuliah Pengembangan Kepribadian di Perguruan Tinggi (Signs for the Implementation of Personality Development Subject Groups in Higher Education). 2006.

[3] Dewi Y, Resti PM. Pengembangan Bahan Ajar Mata Kuliah Strategi Pembelajaran Bahasa Indonesia dengan Metode Pikir Bareng dan Berbagi (Development of Teaching Materials for Indonesian Language Learning Strategies Subjects with Collaborative Thinking and Sharing Methods). Pena: Jurnal Pendidikan Bahasa dan Sastra. 2019;9(1):11628.

[4] Pedoman Penyusunan Kurikulum Pendidikan Tinggi dan Penilaian Hasil Belajar Mahasiswa (Guidelines for Higher Education Curriculum Development and Assessment of Student Learning Outcomes) [Internet]. 2000. Available from:

http://simpuh.kemenag.go.id/regulasi/kepmendiknas 232 0 $0 . p d f$

[5] Kuntarto E. Keefektifan Model Pembelajaran Daring dalam Perkuliahan Bahasa Indonesia di Perguruan Tinggi (The Effectiveness of Online Learning Models in Indonesian Language Lectures in Higher Education). Indonesian Language Education and Literature. 2017 Dec 12;3(1):99110

[6] Yuliarti Y. Pengembangan Buku Ajar Mata Kuliah Bahasa Indonesia Untuk Mahasiswa STMIK Palangka Raya (Development of Indonesian Language Textbooks for STMIK Palangka Raya Students). Jurnal Pendidikan Surya Edukasi (JPSE). 2016;2(2):76-95.

[7] Rahmiati R, Arsyad A, Yaumi M, Asik N, Rasyid MNA. The Development of Indonesian Language Teaching Materials Based on Knowledge Integration in Islamic Higher Education. RETORIKA: Jurnal Bahasa, Sastra, dan Pengajarannya. 2019 Aug 15;12(2):165-76.

[8] Gai F. Construction of ESP Teaching System. JLTR. 2017 Nov 1;8(6):12041209.

[9] Ulfah A, Jumaiyah J. Pengembangan Bahan Ajar Mata Kuliah Bahasa Indonesia di Perguruan Tinggi Kabupaten Lamongan (Development of Teaching Materials for Indonesian Language Courses at Higher Education in Lamongan Regency). Jurnal Inovasi Pendidikan [Internet]. 2018 Dec 22 [cited 2020 Jun 24];2(1). Available from: http://www.riset.unisma.ac.id/index.php/fkip/article/view/1 730

[10] Jamal N. Model-Model Integrasi Keilmuan Perguruan Tinggi Keagamaan Islam (Models of Scientific Integration in Islamic Religious Higher Education). KABILAH : Journal of Social Community. 2017 Oct 13;2(1):83-101.

[11] Cahyo SD, Muslim MRU, Rahman AN, Pratolo BW. Needs analysis of Islamic-based English reading material for the Muhammadiyah junior high school. International Journal of Evaluation and Research in Education (IJERE). 2019 Jun $1 ; 8(2): 286-92$.

[12] Helaluddin. Analisis Kebutuhan dalam Redesain Silabus (RPS) Mata Kuliah Bahasa Indonesia di Perguruan Tinggi 
(Needs Analysis in Redesigning Syllabus (RPS) of Indonesian Language Courses in Higher Education). Jurnal Gramatika: Jurnal Penelitian Pendidikan Bahasa dan Sastra Indonesia. 2018 Apr 1;4(1):85-103.

[13] Hamsiah H, Tang MR, Tolla A, Jufri J. Teaching Materials Development for Basic General Course of Indonesian Language Class Based on Culture Values Elompungi (Elong) Bugis Literature. Journal of Language Teaching and Research. 2017 Mar 1;8(2):278-85.

[14] Irwansyah D. Islamic Literature: Instructional Strategies in Contemporary Indonesia. Heritage of Nusantara: International Journal of Religious Literature and Heritage. 2019 Oct 24;8(1):1-17.

[15] vanovic M, Budimac Z, Mishev A, Bothe K, Jurca I. Java across Different Curricula, Courses and Countries Using a Common Pool of Teaching Material. Informatics in Education. 2013;12(2):153-79.

[16] Isodarus PB. Pembelajaran Bahasa Indonesia Berbasis Teks (Indonesian Language Learning Based on Text). Sintesis. 2017 Mar 1;11(1):1-11.

[17] Katalayi GB, Sivasubramaniam S. The Construct Validity of a Reading Test Based on Narrative Texts. Journal of Language Teaching and Research. 2015 Jan 25;6(1):21-9.

[18] Irwan I. Model Pengembangan Soal Reading TOEFL Berbasis Teks-Teks Keislaman (TOEFL Reading Problem Development Model Based on Islamic Texts). Ta'dib. 2017 Mar 15;19(2):165-82.

[19] Ikhwan A. Perguruan Tinggi Islam Dan Integrasi Keilmuan Islam (Islamic Higher Education and Islamic Scientific Integration). At-Tajdid: Jurnal Ilmu Tarbiyah. 2016 Aug $30 ; 5(2): 159-87$

[20] Soeyono Y. Pengembangan Bahan Ajar Matematika dengan Pendekatan Open-ended untuk Meningkatkan Kemampuan Berpikir Kritis dan Kreatif Siswa SMA (Development of Mathematics Teaching Materials with an Open-ended Approach to Improve High School Students' Critical and Creative Thinking Ability). Pythagoras: Jurnal Pendidikan Matematika. 2014 Dec 10;9(2):205-18.

[21] BSNP. Permendiknas RI No. 22 Tahun 2006 tentang Standar Isi untuk Satuan Pendidikan Dasar dan Menengah (Permendiknas RI No. 22 of 2006 concerning Content Standards for Primary and Secondary Education Units). Jakarta; 2006.

[22] Arsyad N. Model Pembelajaran Matematika yang Menumbuhkan Kemampuan Metakognisi untuk Menguasai Bahan Ajar (Mathematics Learning Model That Fosters
Metacognitive Ability to Master Teaching Materials). Disertasi tidak diterbitkan Surabaya: PPs Universitas Negeri Surabaya. 2007;

[23] Sugiyono. Metode penelitian pendidikan, pendekatan kuantitatif, kualitatif dan R\&D (Educational research methods, quantitative, qualitative and $\mathrm{R} \& \mathrm{D}$ approaches). Bandung: Alfabeta; 2010.

[24] Mohammed SAH. Investigating the Application of Needs Analysis on EAP Business Administration Materials. ELT. 2016 Feb 13;9(3):74.

[25] Čapková H, Kroupová J. Language Needs Analysis of Students of Economic. ERIES Journal. 2017 Mar 31;10(1):1-6.

[26] Nurgiyantoro B, Efendi A. Re-actualisation of Puppet Characters in Modern Indonesian Fictions of the 21st Century. 3L: Language, Linguistics, Literature $\mathbb{}($ Internet]. 2017 Jun 22 [cited 2020 Jul 6];23(2). Available from: http://ejournals.ukm.my/31/article/view/16705

[27] Sodiq S. Developing Language Learning Textbooks Enriched with Sense of Literacy: The Case of Junior High School in Indonesia. International Education Studies. 2015 Aug 27;8(9):p120.

[28] Alwan AAN, Yusoff MYBM, Al-Hami MSM. Analytical Models of Legislative Texts for Muslim Scholars. IES. 2011 Jan 12;4(1):p230.

[29] Tekerek M, Tekerek B. Integrated instructional material and development processes. Turkish Journal of Education. 2018 Jul 31;7(3):156-68.

[30] Mir NA, Sultana AS. An Interdependence of Materials, Teaching Practices \& Policy: A Study. Theory and Practice in Language Studies. 2016 May 17;6(5):907-18.

[31] Yachina NP, Valeeva LA, Sirazeeva AF. E-Teaching Materials as the Means to Improve Humanities Teaching Proficiency in the Context of Education Informatization. International Journal of Environmental \& Science Education. 2016;11(4):10.

[32] Yaumi M. Pengembangan Bahan Ajar English for Spesific Purpose Berbasi TIK (Development of ICT-Based English for Specific Purpose Teaching Materials). Lentera Pendidikan : Jurnal Ilmu Tarbiyah dan Keguruan. 2017 Dec $3 ; 15(2): 144-60$.

[33] Diktis Kemenag. SILK - Sistem Informasi dan Layanan Kelembagaan (Information Systems and Institutional Services) [Internet]. 2020 [cited $2020 \mathrm{Jul}$ 7]. Available from: http://diktis.kemenag.go.id/rankingptai/ 